\title{
Corrosion Inhibition Efficiency Prediction of Imidazole Derivatives: A quantum Chemical Study
}

\author{
Saprizal Hadisaputra ${ }^{1}$, Zohrul Iskandar ${ }^{2}$, Dina Asnawati ${ }^{2}$ \\ ${ }^{1}$ Chemistry Education Divison,University of Mataram.JalanMajapahit No 62 Mataram, 83125, Indonesia. \\ ${ }^{2}$ Department of Chemistry, Faculty of Mathematics and Natural Science, University of Mataram, Indonesia \\ *Email: rizal@unram.ac.id
}

Received December 03, 2018; Accepted February 10, 2019

\begin{abstract}
Corrosion is a process of metal destruction due to the metal-acidic environment reaction. The uncontrolled corrosion process lead to massive losses. Administering inhibitors of organic compounds on the metal surface may prevent the corrosion processes. Organic inhibitors are low toxicity, environmentally friendly, effective easy to obtain and cheap. The study aims to determine the effect of substituents to the efficiency of corrosion inhibition of imidazole in carbon steel based on quantum chemical parameters. Corrosion inhibition efficiency values are strongly influenced by the addition of substituents namely electron donors $\left(\mathrm{CH}_{3}, \mathrm{CHCH}_{2}, \mathrm{NH}_{2}, \mathrm{CH}_{2} \mathrm{OH}\right.$ and $\left.\mathrm{OH}\right)$ and electron withdrawal $\left(\mathrm{CHO}, \mathrm{COOH}, \mathrm{NO}_{2}, \mathrm{~F}\right.$ and $\left.\mathrm{Cl}\right)$. The addition of amine group $\mathrm{NH}_{2}$ increased the corrosion inhibition efficiency to $91 \%$ whereas amino group $\mathrm{NO}_{2}$ reduced the efficiency of corrosion inhibition to $64 \%$. Analysis of the Fukui function shows that imidazole has active sides on the $\mathrm{C} 1$ and $\mathrm{C} 3$ atoms. NBO analysis shows that there is an interaction of N5 atoms that donate electrons to $\mathrm{Fe} 13$ at $8.67 \mathrm{kcal}^{\mathrm{mol}-}{ }^{-}$. In conclusion, the addition of an electron donor group increases the efficiency of corrosion inhibition of imidazole.
\end{abstract}

Keywords: corrosion; organic inhibitors; imidazole; DFT; substituent

\section{PENDAHULUAN}

Baja karbon merupakan logam paduan yang terdiri dari besi dan karbon. Baja karbon rendah biasanya sangat mudah mengalami korosi. Korosi baja karbon adalah masalah yang signifikan dalam produksi dan sistem transportasi migas yang menyebabkan kerugiaan ekonomi yang cukup besar [1-2]. Kerugian yang dialami akibat korosi diperkirakan mencapai 2-5 persen dari produk bruto suatu negara. Dampak negatif korosi dapat menyebabkan kerugian, sehingga perlu dilakukan kajian untuk menghambat laju korosi melalui pemberian inhibitor pada besi ataupun baja karbon [1]. Inhibitor anorganik memiliki kelemahan utama yaitu bersifat toksik dan tidak ramah lingkungan. Oleh karena itu, inhibitor yang digunakan yaitu inhibitor organik karena berasal dari tumbuhan yang bersifat aman dan ramah lingkungan [3-4].

Inhibitor korosi organik sebagai alternatif karena memiliki sifat aman, mudah didapatkan, bersifat biodegradable, biaya murah dan ramah lingkungan. Salah satu faktor yang dapat mempengaruhi efisiensi penghambat korosi suatu senyawa organik adalah keberadaan heteratom seperti $\mathrm{O}, \mathrm{N}, \mathrm{S}$ dan $\mathrm{P}$ pada suatu molekul. Kehadiran kelompok fungsional yang tepat akan membantu pembentukan senyawa kompleks yaitu antara senyawa organik dan permukaan logam atau yang dapat membantu adsorpsi inhibitor molekul pada permukaan logam. Molekul inhibitor organik dapat membentuk lapisan dan dapat mencegah permukaan logam dari kontak dengan media korosif [5].

Imidazol merupakan senyawa organik aromatik heterosiklik dengan rumus kimia $\mathrm{C}_{3} \mathrm{H}_{4} \mathrm{~N}_{2}$ dengan memiliki atom nitrogen terdapat gugus polar dan/atau elektron phi yang bisa menjadi kandidat kuat sebagai inhibitor korosi yang efisien dalam media asam. Hal ini dikarenakan, jenis molekul organik ini dapat diadsorpsi pada permukaan logam karena adanya ikatan yang dapat terbentuk antara pasangan elektron $\mathrm{N}$ dan/atau awan elektron phi, sehingga dapat mengurangi sifat korosif suatu logam dalam media asam [6-7]. Imidazol dapat mencegah terjadinya korosi di lingkungan petroleum yang disebabkan oleh $\mathrm{CO}_{2}$ pada sumur minyak, sumur gas dan sistem pipa [6]. Kajian eksperimen senyawa imidazol sebagai inhibitor korosi telah dilakukan [8] terhadap baja karbon dalam media asam sulfat $0,5 \mathrm{M}$ dan menunjukkan nilai efisiensi inhibisi imidazol sebesar $77,50 \%$. Kajian teoritis senyawa imidazol sebagai inhibitor korosi telah dilakukan. Efisiensi inhibisi korosi tersebut masih 
bisa ditingkatkan dengan penambahan substituen menggunakan kajian teoritis dengan bantuan kimia komputasi.

Kajian teoritis senyawa thiaamidapirazolindol dilakukan [9] memiliki efisiensi inhibisi sebesar $82,82 \%$ dan mengalami kenaikan efisiensi inhibisi pada substituen $-\mathrm{NH}_{2}$ menjadi $98,76 \%$. [10] melakukan kajian teoritis senyawa dibenzo-18-crown-6 memiliki efisiensi inhibisi $63,13 \%$ dan mengalami kenaikan efisiensi inhibisi pada substituen $-\mathrm{NH}_{2}$ menjadi $68,64 \%$ sedangkan substituen $-\mathrm{NO}_{2}$ mengalami penurunan sebesar $53,40 \%$.

Senyawa imidazol dengan kajian teoritis sebagai inhibitor korosi untuk dapat ditingkatkan nilai efisiensi. Kajian teoritis ini menggunakan substituen pendorong elektron $\left(\mathrm{CH}_{3}, \mathrm{CHCH}_{2}\right.$, $\left.\mathrm{NH}_{2}, \mathrm{CH}_{2} \mathrm{OH}, \mathrm{OH}\right)$ dan penarik elektron $(\mathrm{CHO}$, $\mathrm{COOH}, \mathrm{NO}_{2}, \mathrm{~F}$ dan $\mathrm{Cl}$ ). Metode ini memiliki beberapa keuntungan seperti waktu pekerjaan yang singkat, aman untuk tubuh manusia dan tidak ada buangan bahan kimia [10-11]

\section{METODE PENELITIAN}

Penelitian ini dilakukan dengan menggunakan metode kimia komputasi. Perhitungan ini dilakukan dengan menggunakan aplikasi Gaussian 09W [12]. Secara teoritis perhitungan parameter kuantum seperti potensial ionisasi (I) dan afinitas elektron (A) menggunakan teorema dari Koopman [13]. Teorema Koopman dapat menjelaskan hubungan antara potensial ionisasi (I), afinitas elektron (A) dengan tingkatan energi (HOMO dan LUMO) dengan persamaan (1) (2) sebagai berikut:

$$
\begin{aligned}
& \mathrm{I}=-\mathrm{E}_{\text {HOMO }} \\
& \mathrm{A}=-\mathrm{E}_{\text {LUMO }}
\end{aligned}
$$

Elektronegativitas $(\chi)$ dapat dihitung dengan persamaan (3) sebagai berikut [14]:

$$
\chi=\frac{\mathrm{I}+\mathrm{A}}{2}
$$

Hardness $(\eta)$ dapat dihitung berdasarkan persamaan (4) sebagai berikut [14]:

$$
\eta=\frac{\mathrm{I}-\mathrm{A}}{2}
$$

Jumlah transfer elektron $(\Delta N)$ dapat dihitung berdasarkan persamaan (5) sebagai berikut [15]:

$$
\Delta \mathrm{N}=\frac{\chi \mathrm{Fe}-\chi \mathrm{Inh}}{2(\eta \mathrm{Fe}+\eta \operatorname{inh})}
$$

Efisiensi inhibisi korosi secara teoritis telah dihitung menggunakan persamaan $(6),(7), 8)$ sebagai berikut[16]:

$$
I_{\text {add }} . \%=\frac{I_{I n h}-I_{x-\operatorname{Inh}}}{I_{\text {Inh }}} \times 100
$$

$$
\begin{aligned}
I E_{\text {add }} \cdot \% & =I_{\text {add }} \cdot \%-I_{\text {eInh }} \% \\
I E_{\text {teori }} . \% & =I_{\text {eInh }} \%+I E_{\text {add }} . \%
\end{aligned}
$$

dengan $I_{a d d} . \%$ adalah persentase potensial ionisasi, $I_{I n h}$ adalah potensial ionisasi senyawa induk, $I_{x}$ adalah potensial ionsisasi senyawa turunan, $I E_{\text {add }} . \%$ adalah persentase efisiensi inhibitor, $I_{\text {eInh }} \%$ adalah efisiensi inhibitor, $I E_{\text {teori }} . \%$ adalah persentase efiesiensi inhibitor secara teori.

Analisis Fungsi Fukui dapat dihitung menggunakan persamaan (9), (10) sebagai berikut [17]:

$$
\begin{aligned}
& f k^{+}=q k(N+1)-q k(N) \\
& f k^{-}=q k(N+1)-q k(N)
\end{aligned}
$$

dengan qk $(\mathrm{N}+1)$ adalah muatan atom $(+1)$ dalam senyawa, qk $(N)$ adalah muatan atom $(0)$ dalam senyawa, qk $(\mathrm{N}-1)$ adalah muatan atom (-1) dalam senyawa, $\mathrm{k}^{+}$adalah serangan nukleofilik, dan $\mathrm{fk}^{-}$adalah serangan elektrofilik.

Energi stabilisasi $\left(E^{2}\right)$ dapat dihitung menggunakan persamaan (11) sebagai berikut [17]:

$$
E^{2}=\Delta E_{i j}=\left(\frac{F_{i j^{2}}}{E_{j}-E_{i}}\right)
$$

dengan qi adalah orbital yang terisi elektron dari orbital pendonor, $\left.E_{(i, j)}\right)$ adalah donor akseptor , $F_{(i, j)}$ merupakan elemen Fock matrix antara orbital pendonor dan akseptor serta $E^{2}$ adalah energi stabilisasi.<smiles>[R]c1ncc[nH]1</smiles>

Gambar 1 Struktur molekul senyawa imidazol dan turunan. $\mathrm{R}=-\mathrm{CHO},-\mathrm{COOH},-\mathrm{F},-\mathrm{Cl},-\mathrm{NO}_{2}$ (Penarik elektron); $\mathrm{R}=\mathrm{CH}_{3},-\mathrm{CHCH}_{2},-\mathrm{OH}$, $\mathrm{CH}_{2} \mathrm{OH},-\mathrm{NH}_{2}$ (Pendonor elektron)

\section{HASIL DAN PEMBAHASAN}

Penelitian ini dilakukan dengan kajian teoritis dengan menggunakan kimia komputasi untuk dapat mengetahui pengaruh penambahan substituen terhadap nilai efisiensi inhibisi korosi senyawa imidazole dan turunan. Kajian teoritis ini dilakukan untuk mencari metode terpilih, menghitung nilai efisiensi inhibisi korosi berdasarkan parameter kimia kuantum, memprediksi sisi aktif dan pola interaksi molekul dengan logam besi. Adapun struktur dari senyawa imidazol dan turunan dapat dilihat pada 
Gambar 1. Struktur molekul 2-metil imidazol pada kajian teoritis dapat memberikan informasi mengenai jarak ikat dan sudut ikat sehingga dapat digunakan untuk membandingkan

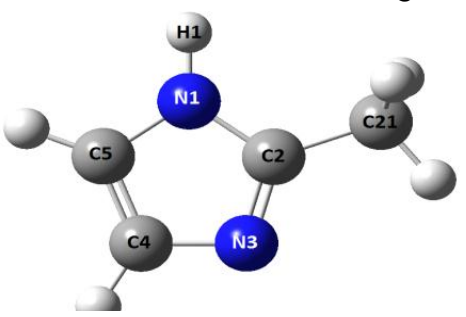

(a) selisihnya dengan struktur kristal hasil eksperimen. Hal tersebut dapat dilihat pada Gambar 2 dan Tabel 2.

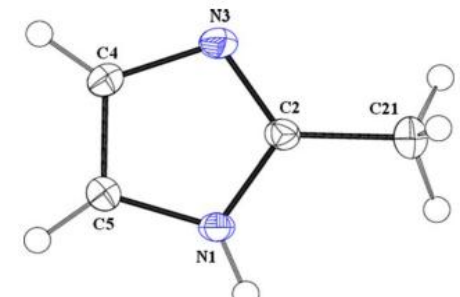

(b)

Gambar 2 Struktur (a) 2-metil imidazol (b) kristal 2-metil imidazol [20]

Tabel 1 Perbandingan panjang ikatan $(\AA)$ dan sudut ikat $(\stackrel{\circ}{)}$ hasil perhitungan teoritis menggunakan metode DFT 6-311++G $(d, p)$ dengan eksperimen [20]

\begin{tabular}{|c|c|c|c|c|c|}
\hline Jarak Ikat & $\begin{array}{c}\text { Teoritis } \\
(\AA)\end{array}$ & $\begin{array}{c}\text { Eksperimen } \\
(\AA \AA)\end{array}$ & Sudut lkat & $\begin{array}{c}\text { Teoritis } \\
(\stackrel{0}{)})\end{array}$ & Eksperimen $(\stackrel{\circ}{)}$ \\
\hline N1-C2 & 1,372 & 1,347 & C2-N1-C5 & 107,71 & 107,40 \\
\hline N1-C5 & 1,382 & 1,370 & N3-C2-N1 & 110,80 & 111,46 \\
\hline $\mathrm{N} 1-\mathrm{H} 1$ & 1,009 & 0,87 & C2-N3-C4 & 105,80 & 105,02 \\
\hline N3-C2 & 1,319 & 1,327 & C5-C4-N3 & 110,78 & 109,89 \\
\hline N3-C4 & 1,378 & 1,384 & C4-C5-N1 & 104,89 & 106,22 \\
\hline C4-C5 & 1,370 & 1,356 & N3-C2-C21 & 125,86 & 125,50 \\
\hline C2-C21 & 1,495 & 1,487 & $\mathrm{~N} 1-\mathrm{C} 2-\mathrm{C} 21$ & 123,33 & 123,03 \\
\hline
\end{tabular}

Berdasarkan Tabel 1 menunjukkan

bahwa hasil selisih antara data kajian eksperimen dengan teoritis senyawa 2-metil imidazol dari jarak ikat diperoleh 0,03 (Å) dan sudut ikat diperoleh $0,65(\stackrel{\circ}{)}$. Hasil yang baik menunjukkan bahwa memiliki selisih jarak ikat yaitu $\sim 0.1$ (Å) dan sudut ikat sekitar 0,1 $-0,2\left(^{\circ}\right)$ [21]. Metode terpilih yang digunakan adalah DFT dengan himpunan basis $6-311++G(d, p)$ untuk penentuan parameter kimia kuantum pada senyawa imidazol karena memiliki akurasi yang tinggi sehingga telah memenuhi syarat. Parameter kuantum berfungsi untuk menentukan sifat struktur berdasarkan data kajian teoritis sehingga dapat memprediksi nilai efisiensi inhibisi senyawa imidazol dan turunan, seperti tingkatan energi HOMO, potensial ionisasi, elektronegativitas dan transfer elektron [34].

Tabel 2 Parameter kuantum dan persentase efisiensi inhibisi imidazol dan turunan

\begin{tabular}{ccccccccc}
\hline & $\begin{array}{c}\mathrm{E}_{\text {Hомо }} \\
\mathrm{eV}\end{array}$ & $\begin{array}{c}\mathrm{E}_{\text {LUMO }} \\
\mathrm{eV}\end{array}$ & $\begin{array}{c}\mathrm{E}_{\text {gap }} \\
\mathrm{eV}\end{array}$ & $\begin{array}{c}\mathrm{IP} \\
\mathrm{Ev}\end{array}$ & $\begin{array}{c}\mathrm{X} \\
\mathrm{eV}\end{array}$ & $\begin{array}{c}\Delta \mathrm{N} \\
\mathrm{eV}\end{array}$ & $\begin{array}{c}\text { Teori } \\
\text { Efisiensi } \\
\text { inhibisi } \\
\%\end{array}$ & $\begin{array}{c}\text { Eksperimen } \\
\text { Efisiensi } \\
\text { inhibisi } \\
\%\end{array}$ \\
\hline $\mathrm{NH}_{2}$ & $-5,3835$ & $-0,6732$ & 4,7103 & 5,3835 & 3,0284 & 0,8432 & 91,3713 & - \\
$\mathrm{CHCH}_{2}$ & $-6,0298$ & $-1,1053$ & 4,9244 & 6,0298 & 3,5676 & 0,6970 & 83,7329 & - \\
$\mathrm{OH}$ & $-6,0864$ & $-0,4351$ & 5,6513 & 6,0864 & 3,2607 & 0,6617 & 83,0640 & - \\
$\mathrm{CH}_{2} \mathrm{OH}$ & $-6,2058$ & $-0,6435$ & 5,5623 & 6,2058 & 3,4247 & 0,6428 & 81,6521 & - \\
$\mathrm{CH}_{3}$ & $-6,2355$ & $-0,5186$ & 5,7168 & 6,2355 & 3,3771 & 0,6337 & 81,3015 & - \\
$\mathrm{H}$ & $-6,5571$ & $-0,5206$ & 6,0366 & 6,5571 & 3,5388 & 0,5734 & 77,5000 & $77,50[8]$ \\
$\mathrm{Cl}$ & $-6,6584$ & $-0,5551$ & 6,1032 & 6,6584 & 3,6067 & 0,5560 & 76,3036 & - \\
$\mathrm{F}$ & $-6,7005$ & $-0,5704$ & 6,1302 & 6,7005 & 3,6354 & 0,5489 & 75,8051 & - \\
$\mathrm{COH}$ & $-7,0679$ & $-1,7388$ & 5,3291 & 7,0679 & 4,4033 & 0,4873 & 71,4633 & - \\
$\mathrm{CHO}$ & $-7,1571$ & $-2,1687$ & 4,9884 & 7,1571 & 4,6629 & 0,4685 & 70,4083 & - \\
$\mathrm{NO}_{2}$ & $-7,6970$ & $-3,1647$ & 4,5323 & 7,6970 & 5,4309 & 0,3462 & 64,0275 & - \\
\hline
\end{tabular}




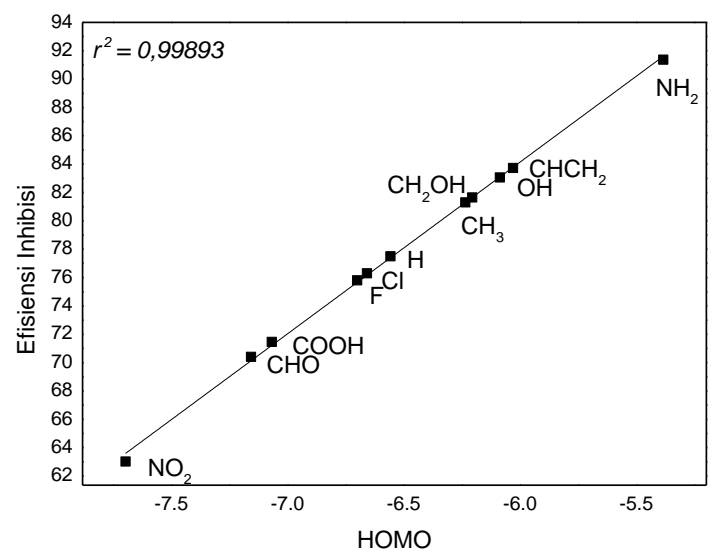

(a)

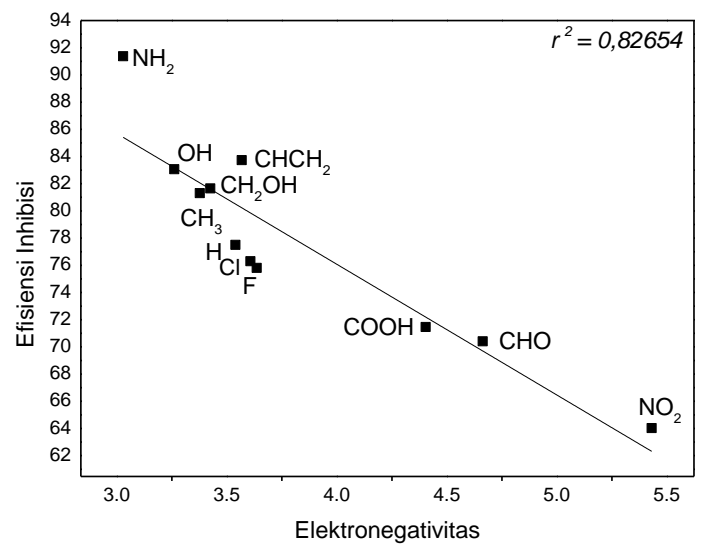

(c)

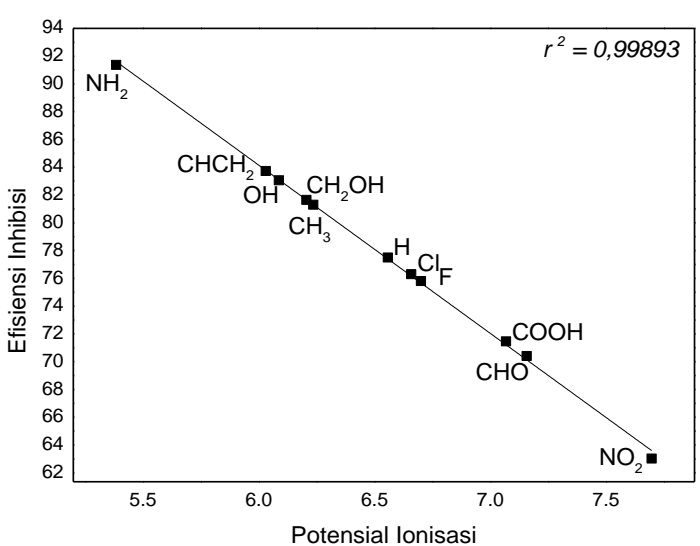

(b)

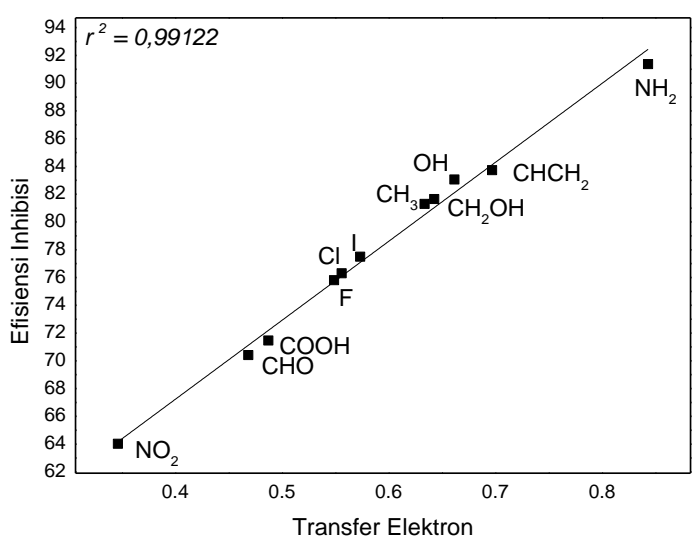

(d)

Gambar 3 Hubungan antara (a) energi HOMO (b) Potensial ionisasi (c) Elektronegativitas (d) Transfer elektron dengan efisiensi inhibisi

Tabel 3 Fungsi Fukui senyawa imidazol dan turunan

\begin{tabular}{c|cccccc}
\hline Substituen & Atom & $\mathrm{N}-$ & $\mathrm{N}$ & $\mathrm{N}+$ & $f^{+}$ & $f^{-}$ \\
\hline $\mathrm{H}$ & $\mathrm{C} 1$ & 0,0243 & $-0,1099$ & 0,0243 & 0,1342 & 0,1342 \\
& $\mathrm{~N} 2$ & $-0,2313$ & $-0,2057$ & $-0,2313$ & 0,0256 & 0,0256 \\
& $\mathrm{C} 3$ & 1,2427 & $-0,1913$ & 1,2427 & 1,4339 & 1,4339 \\
& $\mathrm{C} 4$ & 0,9139 & $-0,0718$ & 0,9139 & 0,9856 & 0,9856 \\
& $\mathrm{~N} 5$ & 0,0741 & $-0,1627$ & 0,0741 & 0,2368 & 0,2368 \\
\hline $\mathrm{NH}_{2}$ & $\mathrm{C} 1$ & 0,3133 & $-0,1939$ & 0,0182 & 0,2120 & 0,5072 \\
& $\mathrm{~N} 2$ & 0,0595 & $-0,2497$ & $-0,2074$ & 0,0423 & 0,3092 \\
& $\mathrm{C} 3$ & 1,2790 & 0,1427 & 0,1339 & 0,0088 & 1,1363 \\
& $\mathrm{C} 4$ & 0,3814 & $-0,1203$ & $-0,0499$ & 0,0705 & 0,5017 \\
& $\mathrm{~N} 5$ & $-0,1477$ & $-0,2729$ & $-0,1374$ & 0,1355 & 0,1252 \\
& $\mathrm{~N} 6$ & -0.6996 & $-0,4315$ & $-0,2603$ & 0,1711 & 0,2681 \\
\hline $\mathrm{NO}_{2}$ & $\mathrm{C} 1$ & $-0,2422$ & $-0,1228$ & 0,0425 & 0,1653 & 0,1193 \\
& $\mathrm{~N} 2$ & $-0,1915$ & $-0,1586$ & $-0,1103$ & 0,0484 & 0,0328 \\
& $\mathrm{C} 3$ & $-0,0495$ & $-0,0120$ & 0,0456 & 0,0576 & 0,0374 \\
& $\mathrm{C} 4$ & 0,0213 & 0,0147 & 0,1336 & 0,1188 & 0,0066 \\
& $\mathrm{~N} 5$ & $-0,2251$ & $-0,1321$ & $-0,0318$ & 0,1003 & 0,0930 \\
& $\mathrm{~N} 6$ & $-0,2996$ & $-0,2591$ & $-0,2551$ & 0,0040 & 0,0405 \\
& $\mathrm{O} 7$ & $-0,2180$ & 0,0237 & 0,1319 & 0,1082 & 0,2417 \\
& $\mathrm{O} 8$ & $-0,2975$ & $-0,0582$ & 0,0562 & 0,1144 & 0,2393 \\
\hline
\end{tabular}


Hasil perhitungan menunjukkan bahwa penambahan substituen gugus pendonor amina ($\mathrm{NH}_{2}$ ) dapat meningkatkan nilai efisiensi inhibisi menjadi 91,3713 \% dibandingkan dengan penambahan substituen gugus penarik elektron nitro $\left(-\mathrm{NO}_{2}\right)$ mengalami penurunan efisiensi menjadi $64,0275 \%$ pada senyawa imidazol memiliki efisiensi $77,5000 \%$. Berdasarkan penelitian yang telah dilakukan [10] dan [9] substituen $-\mathrm{NH}_{2}$ dapat meningkatkan nilai efisiensi sedangkan mengalami penurunan efisiensi inhibisi pada substituen $-\mathrm{NO}_{2}$. Hal ini sesuai yang telah dilakukan oleh [22] pada senyawa benzimdazol yang dapat menyebabkan berkurangnya nilai efisiensi inhbisi korosi pada gugus nitro $\left(-\mathrm{NO}_{2}\right)$. [23] menyatakan bahwa adanya pengaruh substituen nitro dapat memperlambat reaktivitas pada senyawa imidazol dan tidak baik digunakan sebagai efisiensi inhibitor.

Energi HOMO memiliki sifat molekul untuk dapat mendonasikan elektron yang dimilikinya, semakin besar nilai energi HOMO maka semakin kuat suatu senyawa organik untuk melekat pada permukaan logam sehingga memiliki efisiensi yang tinggi [9]. Nilai energi HOMO yang besar pada senyawa dapat lebih mudah mendonasikan pasangan elektron bebasnya ke atom besi untuk dapat berinteraksi membentuk senyawa kompleks [24]. Berdasarkan Tabel 3 menunjukkan bahwa nilai energi HOMO tertinggi pada substituen $-\mathrm{NH}_{2}$ yaitu $-5,3835 \mathrm{eV}$ karena memiliki sifat sebagai pendonor elektron sedangkan nilai energi $\mathrm{HOMO}$ terendah dibandingkan pada substituen $-\mathrm{NO}_{2}$ yaitu $-7,6970$ $\mathrm{eV}$ karena memiliki sifat sebagai penarik elektron. Adapun dapat dilihat pada Gambar 3 hubungan antara energi HOMO dengan efisiensi inhibisi yang memiliki korelasi yang linier sebesar $r^{2}=$ $0,99893$.

Potensial ionisasi memiliki nilai yang rendah menunjukkan bahwa mudahnya suatu atom melepaskan elektron terluarnya sehingga dapat mendonorkan elektron dari molekul ke permukaan logam. Berdasarkan Tabel 3 menunjukkan nilai potensial ionisasi yang tertinggi pada substituen $-\mathrm{NH}_{2}$ yaitu $5,3835 \mathrm{eV}$ sedangkan nilai potensial ionisasi terendah pada substituen $\mathrm{NO}_{2}$ yaitu 7,6970 eV. Nilai efisiensi inhibisi dapat diprediksikan bahwa nilai yang lebih tinggi dengan penambahan substituen $-\mathrm{NH}_{2}$ sedangkan nilai efisiensi inhibisi yang lebih rendah dengan substituen $\mathrm{NO}_{2}$ pada senyawa imidazol. Hal ini disebabkan pada substituen $-\mathrm{NH}_{2}$ lebih reaktif dibandingkan dengan logam besi sehingga suatu molekul organik semakin kuat untuk melekat pada kation logam. Nilai efisiensi inhibisi dapat dipengaruhi nilai potensial ionisasi dapat dilihat pada Gambar 3 memiliki korelasi sebesar $r^{2}=0,99893$.

Menurut [25] interaksi antara inhibitor dengan logam akan bergerak elektronnya dari molekul yang memiliki nilai elekronegatifan rendah menuju molekul yang memiliki elektronegatifan yang tinggi. Secara teoritis nilai elektronegatifan pada besi $7 \mathrm{eV}$ lebih tinggi dibandingkan nilai elektronegatifan pada $-\mathrm{NH}_{2}$ yaitu 3,0284 eV sehingga lebih cenderung melepaskan elektronnya dari penambahan substituen $-\mathrm{NH}_{2}$. Nilai elektronegatitas pada Tabel 3 menunujukkan bahwa dapat diperediksi bahwa substituen $-\mathrm{NH}_{2}$ memiliki efisiensi inhibisi yang tinggi dibandingkan dengan substituen $\mathrm{NO}_{2}$.

Nilai dari transfer elektron menunjukkan bahwa adanya pengaruh inhibitor yang dihasilkan dari sumbangan elektron. Apabila nilai $\Delta N<3,6$ maka efisiensi inhibisi dapat meningkatkan kemampuan donor elektron pada permukaan logam [26]. Adanya gugus pendonor elektron ($\mathrm{NH}_{2},-\mathrm{CH}_{3},-\mathrm{CHCH}_{2},-\mathrm{OH}$ dan $-\mathrm{CH}_{2} \mathrm{OH}$ ) dapat meningkatkan efisiensi inhibisi korosi dan jumlah transfer elektron ke permukaan logam lebih banyak. Berdasarkan Tabel 4.4 menunjukkan bahwa inhibitor korosi terbaik diperoleh pada substituen $-\mathrm{NH}_{2}$ karena memiliki kemampuan jumlah transfer elektron lebih tinggi dibandingankan dengan substituen $-\mathrm{NO}_{2}$ yang terendah. Transfer elektron sangat dipengaruhi nilai efisiensi sehingga memiliki nilai korelasi $r^{2}=$ 0.99122. Analisis fungsi fukui dapat digunakan untuk memprediksi sisi aktif dari suatu molekul. Setiap molekul memililiki sisi aktif yang berbeda sehingga dapat mengetahui gambaran dari sisi aktif yang dapat digunakan dalam berinteraksi. Serangan nukleofilik dan elektrofilik dapat dikendalikan oleh nilai maksimum $f^{+}$dan $f$

[27]. Semakin besar nilai fungsi fukui maka semakin reaktif sisi aktif dari sebuah molekul. Fungsi fukui dapat menjelaskan bahwa nilai $f^{+}$ menunjukkan bahwa kemampuan untuk dapat menerima elektron atau mendonasikan balik dari permukaan logam sedangkan nilai $f$ menunjukkan bahwa adanya donasi elektron atau donasi elektron ke orbital d kosong pada logam atau pada kondisi aktif yang memiliki kaya elektron [27].

Fungsi Fukui dapat menunjukkan bahwa adanya bagian sisi aktif dari setiap molekul. Nukleofilik attact sebagai sisi aktif yang menyerang atom-atom memiliki sedikit elektron. Nilai $f^{+}$maksimum menunjukkan bahwa tempat terjadinya reaktif nukleofilik yang mungkin mampu untuk menerima elektron dari atom logam akan membentuk ikatan donasi balik dengan atom logam [28]. Nukleofilik attact terdapat substituen 
$\mathrm{H}$ pada atom $\mathrm{C} 3$; substituen $-\mathrm{NH}_{2}$ pada atom $\mathrm{C}$; sedangkan substituen $\mathrm{NO}_{2}$ pada atom $\mathrm{C} 1$. Nilai $f^{-}$ maksimum menunjukkan tempat terjadinya atomatom untuk dapat menyediakan elektronnya akan memebentuk ikatan koordinat dengan atom logam. Atom-atom ini dapat diprediksi tempat terjadinya reaktif nukleofilik selama penyerapan terjadi [29]. Berdasarkan Tabel 4 menunjukkan bahwa Elektrofilik attact terdapat substituen $\mathrm{H}$ pada atom $\mathrm{C} 1$; substituen $\mathrm{NH}_{2}$ pada atom $\mathrm{N} 6$ sedangkan substituen $\mathrm{NO}_{2}$ pada atom $\mathrm{O}$.

Pengaruh substituen dalam intensitas donor-akseptor elektron dapat dipelajari lebih lanjut menggunakan energi stabilisasi $\left(E^{2}\right)$ didasarkan pada analisis NBO. Analisis NBO (Natural Bonding Orbital) sebagai energi stabalisasi $\left(E^{2}\right)$ yang dapat digunakan untuk mengetahui interaksi antara orbital tipe NBO occupied dan unoccupied yang berkontribusi terhadap delokalisasi elektron dari bonding (BD) atau lone pair orbital (LP) ke anti-ikatan $\left(\mathrm{BD}^{*}\right)$ [30].

Tabel 4 Energi stabilisasi $\left(E^{2}\right)$ senyawa imidazol dan turunan

\begin{tabular}{|c|c|c|c|c|}
\hline & Donor(i) & $\rightarrow$ & Akseptor(j) & $\begin{array}{c}E^{2} \\
\text { (kkal/mol) }\end{array}$ \\
\hline \multirow[t]{4}{*}{$\mathrm{H}$} & LP N2 & $\rightarrow$ & $\mathrm{LP}^{*} \mathrm{Fe} 10$ & 8,89 \\
\hline & LP N5 & $\rightarrow$ & $\mathrm{LP}^{*} \mathrm{Fe} 10$ & 0,90 \\
\hline & $\mathrm{LP}^{*} \mathrm{Fe} 10$ & $\rightarrow$ & $\mathrm{RY}{ }^{*} \mathrm{~N} 2$ & 7,55 \\
\hline & $\mathrm{LP}^{*} \mathrm{Fe} 10$ & $\rightarrow$ & $R Y^{*} \mathrm{~N} 5$ & 2,18 \\
\hline \multirow[t]{4}{*}{$\mathrm{NH}_{2}$} & LP N2 & $\rightarrow$ & $\mathrm{LP}^{*} \mathrm{Fe} 12$ & 0,57 \\
\hline & LP N5 & $\rightarrow$ & $\mathrm{LP}^{*} \mathrm{Fe} 12$ & 8,67 \\
\hline & $\mathrm{LP}^{*} \mathrm{Fe} 12$ & $\rightarrow$ & $\mathrm{RY} Y^{*} \mathrm{~N} 2$ & 7,48 \\
\hline & $\mathrm{LP}^{*} \mathrm{Fe} 12$ & $\rightarrow$ & $R Y^{*}$ N5 & 11,43 \\
\hline \multirow[t]{3}{*}{$\mathrm{NO}_{2}$} & LP N5 & $\rightarrow$ & $\mathrm{LP}^{*} \mathrm{Fe} 12$ & 5,13 \\
\hline & LP Fe12 & $\rightarrow$ & $R Y^{*} \mathrm{~N} 2$ & 3,36 \\
\hline & LP Fe12 & $\rightarrow$ & $\mathrm{RY}$ * N5 & 2,81 \\
\hline
\end{tabular}

Simbol pada BD (Bonding) menunjukkan bahwa keadaan atom yang berikatan antara satu sama lain. Simbol LP (Lone Pair) menunjukkan bahwa adanya pasangan elektron bebas pada atom yang bersangkutan dengan simbol RY (Rydeberg) yaitu jenis orbital pada atom yang memiliki bilangan kuantum dan energi yang tinggi [30]. Hal ini dapat terjadi dengan adanya donor elektron dari inhibitor ke besi, begitupun sebaliknya logam besi dapat mendonorkan kembali elektronnya ke atom (back bonding).

Nilai-nilai yang dipilih untuk energi stabilisasi $\left(E^{2}\right)$ menunjukkan bahwa adanya pasangan elektron bebas (LP) dari atom nitrogen pada senyawa imidazol dan substituennya, sehingga adanya pasangan elektron bebas antibonding $\left(\mathrm{LP}^{*}\right)$ pada logam Fe yang berinteraksi untuk mendapatkan nilai energi stabilisasi. Semakin besar nilai energi stabilisasi maka ikatannya paling kuat sehingga dapat menyebabkan ikatannya lebih stabil. Berdasarkan Tabel 5 menunjukkan bahwa dalam hasil analisis NBO (Natural Bonding Orbital) untuk senyawa pada imidazol dan substituennya memiliki energi stabilisasi paling maksimum pada substituen $-\mathrm{NH}_{2}$ yaitu sebesar $11,43 \mathrm{kkal} / \mathrm{mol}$ sedangkan nilai energi stabilisasi terendah terdapat pada substituen $-\mathrm{COOH}$ yaitu $0,97 \mathrm{kkal} / \mathrm{mol}$. Adanya donasi elektron secara bersamaan atom nitrogen sehingga dapat mengalami donasi elektron balik dari besi yang memiliki nilai energi stabilisasi yang tinggi.

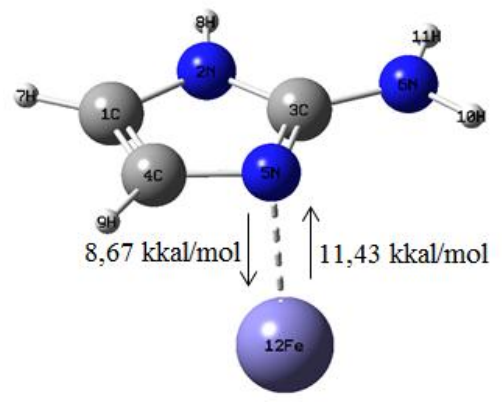

\section{Gambar 4 Donor Acceptor Fe dan Imidazole}

\section{KESIMPULAN}

Berdasarkan pembahahasan dari hasil penelitian yang telah dilakukan maka dapat disimpulkan bahwa Aaalisis Fungsi Fukui menunjukkan bahwa senyawa imidazol memiliki sisi aktif pada atom C1 dan C3. Analisis NBO (Natural Bonding Orbital) menununjukan bahwa adanya pola interaksi dari atom N5 mendonorkan elektron ke atom $\mathrm{Fe} 13$ pada substituen $\mathrm{NH}_{2}$ sebesar 8,67 kkal/mol. Penambahan substituen pendorong elektron $\left(\mathrm{NH}_{2}, \mathrm{CHCH}_{2}, \mathrm{CH}_{3}, \mathrm{CH}_{2} \mathrm{OH}\right)$ dapat meningkatkan nilai efisiensi inhibisi korosi senyawa imidazol sedangkan penambahan substituen penarik elektron $\left(\mathrm{CHO}, \mathrm{COOH}, \mathrm{NO}_{2}\right.$, $\mathrm{F}, \mathrm{Cl})$ dapat menurunkan nilai efisiensi. Berdasarkan parameter kuantum menunjukkan bahwa nilai efisiensi inhibisi mengalami peningkatan pada substituen $-\mathrm{NH}_{2}$ menjadi 91,37 $\%$.

\section{DAFTAR PUSTAKA}

[1] El-Lateef, H. A., Abbasov, V. M., Aliyeva, L. I., \& Ismayilov, T. A. (2012). Corrosion protection of steel pipelines against $\mathrm{CO} 2$ corrosion-a review. Chem. J, 2(2), 52-63.

[2] Yadla, S. V., Sridevi, V., Lakshmi, M. V. V. C., \& Kumari, S. K. (2012). A review on corrosion of metals and protection. International Journal of 
Engineering Science \& Advanced Technology, 2(3), 637-644.

[3] Antonijevic, M. M., \& Petrovic, M. B. (2008). Copper corrosion inhibitors. A review. Int. J. Electrochem. Sci, 3(1), 1-28.

[4] Sanyal, B. (1981). Organic compounds as corrosion inhibitors in different environments-a review. Progress in Organic Coatings, 9(2), 165-236.

[5] Abd El-Maksoud, S. A. (2008). The effect of organic compounds on the electrochemical behaviour of steel in acidic media. A review. International Journal of Electrochemical Science, 3(5), 528-555.

[6] Bereket, G., Hür, E., \& Öğretir, C. (2002). Quantum chemical studies on some imidazole derivatives as corrosion inhibitors for iron in acidic medium. Journal of Molecular Structure: THEOCHEM, 578(13), 79-88.

[7] Zhang, Z., Chen, S., Li, Y., Li, S., \& Wang, L. (2009). A study of the inhibition of iron corrosion by imidazole and its derivatives self-assembled films. Corrosion Science, 51(2), 291-300.

[8] Milošev, I., Kovačević, N., Kovač, J., \& Kokalj, A. (2015). The roles of mercapto, benzene and methyl groups in the corrosion inhibition of imidazoles on copper: I. Experimental characterization. Corrosion Science, 98, 107-118.

[9] Hamdiani, S., Arduha, J., Purwoko, A. A., \& Hadisaputra, S. (2016). Optimasi Sifat Inhibitor Korosi Senyawa ThiaamidaPirazolindol Berdasarkan Teori Fungsional Kerapatan. Jurnal Pijar Mipa, 11(1).

[10] Hadisaputra, S., Hamdiani, S., Kurniawan, M. A., \& Nuryono, N. (2017). Influence of macrocyclic ring size on the corrosion inhibition efficiency of dibenzo crown ether: a density functional study. Indonesian Journal of Chemistry, 17(3), 431-438.

[11] Hadisaputra, S., Purwoko, A. A., Hamdiani, S., \& Nuryono, N. (2019, April). Which anthocyanin is the best corrosion inhibitor? In IOP Conference Series: Materials Science and Engineering (Vol. 509, No. 1, p. 012129). IOP Publishing.

[12]. Frisch, A. (2009). Gaussian 09W Reference. Wallingford, USA, 25p.

[13]. Koopmans, T. (1934). Über die Zuordnung von Wellenfunktionen und Eigenwerten zu den einzelnen Elektronen eines Atoms. Physica, 1(1-6), 104-113.

[14]. Hadisaputra, S., Hamdiani, S., \& Junaidi, E. (2016). Theoretical study on corrosion inhibition properties of 2-isopropyl-5- methylphenol. ALCHEMY Jurnal Penelitian Kimia, 11(2), 102-110.

[15]. Foresman, J., dan Frish, E. (1996). Exploring Chemistry. Gaussian Inc. Pittsburg, USA.

[16]. Obayes, H. R., Alwan, G. H., Alobaidy, A H. M., Al-Amiery, A. A., Kadhum, A. A. H., dan Mohamad, A. B. (2014). Quantum Chemical Assessment of Benzimidazole Derivatives as Corrosion Inhibitors. Chemistry Central Journal, 8(1), 21.

[18]. Hachuła, B., Nowak, M., dan Kusz, J. (2010). Crystal and Molecular Structure Analysis of 2-methylimidazole. Journal of Chemical Crystallography, 40 (3), 201-206.

[21]. Tüzün, B., Kaya, S., dan Kaya, C. (2017). Conceptual Density Functional Theoretical Investigation of The Corrosion Inhibition Efficiencies of Some Molecules Containing Mercapto (-SH) group. Current Physical Chemistry, 7(2), 147-153.

[25]. Lukovits, I., Kalman, E., dan Zucchi, F. (2001). Corrosion Inhibitors-correlation Between Electronic Structure and Efficiency. Corrosion, 57(1), 3-8.

[27]. Hadisaputra, S., Purwoko, A. A., Rahmawati, Asnawati, D., Hamdiani, I. S., \& Nuryono. (2019). Experimental and Theoretical Studies of (2R)-5-hydroxy-7methoxy-2-phenyl-2, 3-dihydrochromen-4one as corrosion inhibitor for Iron in Hydrochloric Acid. International Journal Of Electrochemical Science, 14(12), 1111011121.

[28] Yang, W., dan Parr, R. G. (1985). Hardness, Softness, and the Fukui Function in The Electronic Theory of Metals and Catalysis. Proceedings of the National Academy of Sciences, 82(20), 6723-6726.

[29] Adnani, Z. E., Mcharfi, M., Sfaira, M., Benzakour, M., Benjelloun, A. T., Ebn Touhami, M., Hammouti, B. dan Taleb, M. (2012). DFT study of 7-R3methylquinoxalin-2 (1H)-ones $(R=H$; $\mathrm{CH} 3$; $\mathrm{Cl})$ as corrosion inhibitors in hydrochloric acid. Int. J. Electrochem. Sci, 7, 6738-6751.

[30]. Balachandran, V., Karthick, T., Perumal, S., dan Nataraj, A. (2013). Comparative Theoretical Studies on Natural Atomic Orbitals, Natural Bond Orbitals and Simulated UV-Visible Spectra of N-(Methyl) Phthalimide And N-(2 Bromoethyl) Phthalimide. Vol. 51, pp. 178-184. 